\title{
Lobbying The Supreme Court: Reagan's Solicitor General and the Establishment Clause
}

\author{
Rodney A. Grunes, Centenary College of Louisiana
}

\begin{abstract}
Although professionalism is the expected norm, the Reagan Administration sought to use its solicitor general as an advocate for "social agenda" issues. This was especially apparent in the briefs submitted by the solicitor general to the Supreme Court on behalf of the Government in establishment of religion cases. Although prior research suggested that conservative justices would be influenced by the arguments of a conservative executive, this study indicates that the Supreme Court refused to heed the attempts of President Reagan's solicitor generals to fundamentally alter its approach to resolving establishment clause disputes. Resistance to politicization suggests that there are limits to lobbying by the solicitor general.
\end{abstract}

\section{Introduction}

One of the distinguishing characteristics of the Reagan presidency was its commitment to seek fundamental change on a group of public policy issues commonly referred to as "the social agenda" (Glazer 1986). After failing to convince Congress to enact his views on abortion, criminal justice, civil rights and other "agenda" issues, Ronald Reagan turned to the courts as the main arena for policy change. This seemed appropriate since the Administration's position was based on disagreements with judicially made policies, especially those extending constitutional liberties. Nowhere is this more evident than in the church-state area where the Reagan Administration, through its access to the Supreme Court by the solicitor general, made a sustained effort to alter what was perceived as judicial opposition, if not hostility, to religion.

Although the First Amendment commands that "Congress shall make no law ... respecting an establishment of religion," the Reagan Administration maintained that government had a responsibility to accommodate, if not to promote, religion in American life. In its view, the Supreme Court has misread the original intent of the establishment clause by adopting the Jeffersonian metaphor of a "wall of separation" between church and state. This is most evident in the school prayer decisions (Engel v. Vitale 1962; Abington School District v. Schempp 1963) where, according to Ronald Reagan, the Court "expelled" God from the classroom and denied children the right to pray in school.

President Reagan tried both legislative and judicial remedies to what was viewed as a pattern of usurpation of power by federal judges in matters best left to state and local authorities or to individuals themselves 
(Senate Judiciary Committee 1982, 79). To legislate restoration of the status quo that existed prior to the school prayer decisions, the Administration sought unsuccessfully to limit the jurisdiction of federal courts, and to promote adoption of either a "voluntary vocal prayer" amendment or a "silent prayer" amendment to the constitution (Congressional Record March 15 \& 20, 1984). However, it did persuade Congress to pass tuition tax credits for those with children in parochial schools, as well as the Equal Access Act which permitted student religious clubs to hold meetings on public school grounds on the same basis as other student groups.

In the judicial arena, the Reagan Administration sought to influence the substance of judicial decision-making in two ways. A long-term strategy was to "Reaganize" the judiciary by appointing judges who were ideologically compatible with Reagan's agenda (Goldman 1985, 1989). A second and more immediate strategy was to use the office of Solicitor General to persuade the nation's highest court to adopt Administration views.

The office of Solicitor General was created in 1879 to assist the Attorney General. While arguing cases and writing legal briefs remain the most visible responsibilities, the solicitor general's primary function has been to serve as the "traffic cop" that decides which cases should or should not be presented to the Supreme Court for review (Caplan 1988, 13). Specifically, the solicitor general has discretion to decide whether to seek review of lower court decisions involving the Government and whether to submit amicus curiae briefs where the Government is not a party but has "interests" to protect (Yale Law Journal 1969, 1442-43). Sometimes such briefs have been invited by the justices themselves (Stern 1978, 723-29).

Prior research has demonstrated that the Court has a high regard for briefs submitted by the Government. This is reflected in the federal government's extremely high success rate before the Supreme Court, especially when participating as amicus curiae (Scigliano 1971, 193; O'Connor 1983, 261). It is in this role that the justices have particular regard for the government's position since, as Puro notes, there is no apparent "axe to grind" (1981, 221-22).

Historically, the solicitor general has been viewed as the government's lawyer and a disinterested protector of the public interest, both an officer of the executive branch and an officer of the Court. Conflict between these competing roles has been avoided by the solicitor general's "higher loyalty to the law" (Caplan 1988, 7). As one occupant of the of- 
fice (Simon Sobeloff, 1954-1955) put it, “[m]y client's chief business is not to achieve victory, but to establish justice" (Miller 1968, 63).

The tradition of a politically independent solicitor general was challenged to the extent that the Reagan Administration attempted to use this office to promote "social agenda" issues (Wasby 1984; Caplan 1988). The President thought to make a conservative semaphore of Solicitor General Rex Lee, a Mormon and Dean of the Brighman Young University Law School. From 1981 to 1985, Lee was an assertive solicitor general, "volunteer[ing] the administration's views to the justices more often than any of his predecessors" (Witt 1986, 616). His success rate was an extraordinary 80 to $90 \%$ (Uelmen $1986,361-62$ ).

Although Segal (1988) reports that Lee advanced the conservative position in amicus briefs more often than any attorney general since the Eisenhower years, his replacement, former Harvard Law Professor Charles Fried, was even more aggressive in pressing the Administration's conservative policy positions (Caplan 1988, 185-209). This politicization may have undermined Fried's influence as solicitor general (257).

Yet, past studies suggest that when the justices and solicitor general share a common ideology, the Government's chances for success increase. For example, Scigliano $(1971,185-95)$ found that the government was more successful when it supported the liberal position at a time when liberals dominated the Supreme Court. One expects then, that an increasingly conservative Supreme Court would be responsive to the conservative policies of the solicitor general (Wasby 1984, 104).

This study will examine how successfully the Reagan Administration lobbied the Supreme Court in church-state disputes involving the interpretation of the establishment of religion clause of the First Amendment. The Administration's position and arguments will be gleaned from the written briefs submitted to the court by its solicitor general in two sets of cases: (1) major cases argued during Rex Lee's stewardship, beginning with the 1982-83 Term during which it appeared that the Court was sympathetic to the Government's approach, and (2) those argued while Charles Fried served as solicitor general, from June 1985 to January 1989. Specifically, the analysis will examine (1) what the Reagan Administration wanted the Court to do (which side should prevail), and (2) whether theCourt adopted the reasoning suggested by the solicitor general in his brief. Since our concern is only to assess the fit between what the Administration asked the Court to do and say, and what the justices actually did and said in their resolution of these disputes, no attempt is made to assess the possible impact of briefs submitted by other parties. 


\section{The Early Reagan Years: \\ Raised Expectations?}

During the 1982-83 and 1983-84 terms, the Supreme Court adopted Reagan Administration positions in three major establishment clause cases. The expectations raised thereby proved to be premature.

In Mueller v. Allen (1983), the Reagan Administration asked the Supreme Court to uphold the constitutionality of a Minnesota "tax-deduction" plan which seemed similar to its pledge, stated in the $1980 \mathrm{Re}$ publican Platform, to provide tuition tax credits for parents sending their children to private schools.

Under the Minnesota law, taxpayers were allowed, when computing state income tax liability, to deduct expenses incurred in providing "tuition, textbooks and transportation" for their children attending either public or private elementary and secondary schools. This resulted in a substantially larger tax deduction for parents of students attending parochial and other private schools than for parents of public school children.

Participating as amicus curiae, the Administration acknowledged its support of "federal legislation to provide tax relief for parents who choose nonpublic schools for their children" (Brief of U.S., Mueller 1983, 1). However, to the chagrin of conservatives (Benchmark 1984, 5), the solicitor general challenged neither prior precedents nor the strict "wall of separation" metaphor. Rather, he asked the Court to find the state law constitutional under the three-part Establishment Clause test articulated by the Supreme Court in Lemon v. Kurtzman (1971). Under this test, an enactment is valid if there is (1) a valid secular legislative purpose, (2) a primary effect that neither advances nor inhibits religion, and (3) no excessive governmental entanglement with religion.

According to the Administration, assisting nonpublic schools, enhancing the welfare of all through education, and relieving the burden on public schools constituted convincing evidence of a valid secular purpose (Brief of U.S., Mueller 1983, 8). The primary effect was neutral because the state enacted "a true [tax] deduction," available to all taxpayers with children attending public school and where benefits received by religion were indirect and insubstantial. "Far from encouraging religion," wrote the solicitor general, "the Minnesota deduction simply lessens the disparity between the burdens borne by two classes of state taxpayers (11). Finally, no excessive governmental, entanglement was involved.

The Court's opinion, delivered by Justice Rehnquist, mirrors the Reagan Administration's position in Mueller to a considerable extent. 
Writing for a five justice majority, Rehnquist accepted the Government's argument on the existence of a valid secular purpose. "To defray the cost of educational expenses incurred by parents--regardless of the type of schools their children attend--evidences a purpose that is both secular and understandable" $(1983,395)$. Also, since the tuition tax deduction was "only one among many deductions," Rehnquist concluded that the primary effect did not advance religion.

The Reagan Administration achieved a second major victory in Marsh v. Chambers (1983), the legislative prayer case. Here, a six justice majority found that the establishment clause was not violated by the practice of opening state legislative sessions with a prayer offered by a Presbyterian clergyman who had been paid for sixteen years with public funds. Once again, the court supported the government's position and arguments which were presented amicus curiae.

The Administration's position was that the Court should uphold Nebraska's legislative prayer on the basis of historical evidence and should avoid applying the three-prong Lemon test which was "superfluous" in this kind of case. As the solicitor general explained, the Framers of the Constitution perceived no violation in establishing a chaplaincy for Congress, and the Nebraska chaplaincy "does not deviate in any constitutionally significant way from the kind of legislative chaplaincy envisioned and practiced by the Framers themselves" (Brief of U.S., Marsh 1983, 18).

Writing for the Supreme Court, Chief Justice Burger adopted the historical argument of the Government and avoided the three-prong Lemon framework which had been used by the lower courts to invalidate the legislative prayer. After examining the use of opening prayers in Congress and state legislatures, and the intentions of the Framers of the establishment clause, the Chief Justice concluded:

In light of the unambiguous and unbroken history of more than 200 years, there can be no doubt that the practice of opening legislative sessions with prayer has become part of the fabric of our society. To invoke Divine guidance of a public body entrusted with making the laws is not ... an 'establishment' of religion or a step toward establishment; it is simply a tolerable acknowledgement of beliefs widely held among the people of this country (Marsh v. Chambers 1983, 792).

This language is remarkably similar to the final words in the solicitor general's brief: 
The Nation's experience with paid legislative chaplaincies over the past 200 years confirms that this practice certainly poses no real threat to religious liberty and is, at most, a 'mere shadow' of a threat in the eyes of few beholders--a shadow that entirely fades in the light of history (Brief of U.S., Marsh 1983, 32).

The Reagan Administration prevailed again in Lynch v. Donnelly (1984), the Rhode Island nativity scene case, where a five justice majority overturned lower court decisions which had struck down governmental support of this avowedly Christian symbol in Pawtucket's annual Christmas display. However, the Court was unwilling to adopt the solicitor general's "historical evidence" rationale.

The Administration's argument, presented in an amicus brief urging reversal, was consistent with what it had maintained in Marsh: historical evidence demonstrated that the establishment clause never intended to prohibit government from acknowledging religion as an important part of our Nation's heritage. "It was never the purpose of the Framers to secularize our public life so rigidly that we cannot continue to mark our public holidays in a manner that includes traditional acknowledgments of their religious character" (Brief of U.S., Lynch 1984, 3).

In what may have been his most forceful statements on accommodation, Rex Lee argued that a total separation of church and state was neither possible nor mandated by the First Amendment; the proper role of government, explained the solicitor general, was one of "benevolent neutrality." The Court was urged to avoid the "analytic overkill" that would result from using the Lemon framework. This was not the kind of "religious preference" that violated the establishment clause; "it is simply a natural acknowledgment of the fact that the holiday includes a religious aspect (Brief of U.S., Lynch 1984, 3).

To be sure, the Supreme Court utilized much of the solicitor general's historical argument. In an opinion written by Chief Justice Burger, the Court noted that there was a long "unbroken history" of governmental acknowledgment of religion and public subsidizing of holidays with religious significance. Christmas, after all, is a national holiday. And he agreed with the solicitor general that the First Amendment did not require the complete separation of church and state; rather, "it affirmatively mandates accommodation, not merely tolerance, of all religions, and forbids hostility toward any" (Lynch v. Donnelly 1984, 673).

However, the Court, unlike the Government, sustained the constitutionality of the Pawtucket crèche under the three part Lemon test. After emphasizing that the Nativity Scene must be viewed in the context of the 
Christmas holiday season, the majority determined that the celebration of a national holiday was a legitimate secular purpose, and that the primary effect advanced religion no more than hundreds of religious paintings that hang in publicly supported museums. Any benefit to a particular faith or religion was "indirect, remote and incidental; display of the crèche is no more an advancement or endorsement of religion than the congressional and Executive recognition of the origins of the Holiday itself. .." (Lynch v. Donnelly 1984, 683).

\section{The 1984-85 Term}

Based on the above victories, it is reasonable to assume that the Reagan Administration expected even greater support for its accommodationist position when the Court agreed to decide seven church-state disputes, including four major cases, during its 1984-85 Term. ${ }^{1}$ After all, there had been no change in Court personnel and five or six justices seemed to support the Government's view.

Although the Government was a participant, either as a direct party or as amicus curiae, in each of the major cases, it met with little success. Conservatives blamed Rex Lee for failing to advance the Reagan agenda in these cases. Caplan $(1988,96)$ maintains that this criticism led to Lee's resignation at the end of this Term.

The Reagan Administration suffered a major defeat in Wallace $v$. Jaffree (1985) where six of the justices found that an Alabama law authorizing a one minute period of silence in public schools for "meditation and prayer" violated the establishment clause of the First Amendment. In the Administration's view, "moment of silence" legislation represented a legitimate way of accommodating those who opposed the Warren Court's school prayer decisions. As the solicitor general explained in his amicus brief supporting Alabama:

We believe that provision for a moment of silence in the public schools is not an establishment of religion, but rather a legitimate way for the government to provide an opportunity for both religious and nonreligious introspection in a setting where, experience has shown, many desire it. It is an instrument of toleration and pluralism, not of coercion or indoctrination. (Brief of U.S., Wallace 1985, 7).

Thus, the moment of silence law, like the released time program upheld by the Supreme Court in Zorach v. Clauson (1952), is seen as a legitimate and neutral program of accommodating those who wish to exercise their freedom of religion. 
Perhaps the most controversial decision made by Rex Lee was to ask the Court to decide this case within the context of the Lemon framework. Caplan has reported that William Bradford Reynolds, President Reagan's Assistant Attorney General for Civil Rights, wanted Lee to support the position taken by District Judge Brevard Hand. Hand had upheld the Alabama law on the basis that the Supreme Court had been misinterpreting the establishment clause since Everson $v$. Board of Education (1947), when it adopted the "wall of separation" approach, and on the basis of his belief that the Bill of Rights did not apply to the states. Writing to Lee, Reynolds urged that "[o]ur position in the Supreme Court should be crafted in such a way as to make abundantly clear that we view Schempp and Engel as wrong and unworthy of respect" $(1988,101)$.

The solicitor general did not heed this advice. Instead of abandoning the Lemon formula, he argued for reform. He called upon the Court to affirm that "the purpose of religious accommodation is constitutionally legitimate, and that the effect of such accommodation, if appropriately neutral and voluntary, is no less so" (Brief of U.S., Wallace 1985, 22). Under this modification, then, allowing public school children to pray or meditate at the beginning of each school day promoted the secular purpose of toleration by providing "an exercise of faith among those who believe, and a wholly secular occasion for those who do not" (20). Moreover, the primary effect part of Lemon is satisfied because instead of advancing religion, the moment of silence law merely removed obstacles preventing the free exercise of religion.

Justice Stevens, writing for the majority, rejected this plea for accommodation and modification of the Lemon test. Noting that Alabama already had a moment of silence law that did not include a prayer option, the Court stated that it was unable to identify any secular purpose in the challenged legislation. The purpose of the Alabama law was to return prayer to the public schools, and making prayer a favored practice was unconstitutional under the establishment of religion clause of the First Amendment.

Other than Justice Powell, who defended Lemon as "the only coherent test a majority of the Court has ever adopted" (Wallace v. Jaffree 1985,63 ), four other justices were willing to consider the solicitor general's call for a modification of this framework. Justice O'Connor, for example, suggested that Lemon should be "reexamined and refined" so as to proscribe only direct governmental action which "endorses" religion. Justice Rehnquist, on the other hand, went beyond the Government's recommendation, coming very close to the position advocated by William 
Bradford Reynolds. He rejected the "wall of separation" metaphor and the Lemon test as unworkable and historically inaccurate. In his view, only the formation of a "national" church or preferring one religious denomination over another was prohibited under the establishment clause. Rehnquist received some support from Justice White who, in his dissent, suggested that he would "support a basic reconsideration of our precedents" (91).

Only Chief Justice Burger was willing to adopt the Government's position in Wallace. In his dissent, he agreed with the solicitor general that the silent moment law "affirmatively furthers the values of religious freedom and tolerance that the Establishment clause was designed to protect" (Wallace v. Jaffree 1985, 89). This was not advancing or "endorsing" religion, because those who choose not to pray may use the moment of silence for nonreligious reflection. "If the government may not accommodate religious needs when it does so in a wholly neutral and noncoercive manner," explained Burger, "the 'benevolent neutrality' that we have long considered the correct constitutional standard will quickly translate into the 'callous indifference' that the Court has consistently held the Establishment Clause does not require" (90).

The Supreme Court also rejected the Government's accommodationist view in Estate of Thornton v. Caldor, Inc. 1985, where, with only Justice Rehnquist dissenting, it struck down a Connecticut law that required employers to give their religious employees a day off for Sabbath observance. Writing for the Court, Chief Justice Burger maintained that the First Amendment prohibited a state from providing Sabbath observers with an absolute and unqualified right to refrain from work on their chosen Sabbath.

In its amicus curiae brief, the Reagan Administration maintained that this enactment should be sustained on the basis of past Court decisions upholding Sunday closing laws and rulings which oblige the state to accommodate Sabbath observances under employment compensation programs. The essence of the Government's argument, however, was that modifications in the Lemon test are required when the governmental purpose is one of promoting the free exercise of religion:

In the context of religious accommodations, the Establishment Clause should not be interpreted in such a way as to condemn as 'nonsecular' the objective of enlarging the scope for individual religious choice, or as 'advancing religion' the effect of removing obstacles to religious practice. The fundamental concerns of the Religion Clauses--liberty and pluralism--are furthered, not hindered, by these accommodations (Brief of U.S., Estate of Thornton $1985,8)$. 
Once again, the Court was not persuaded. Relying on a more traditional application of the "primary effect" element of Lemon, the Chief Justice found that the state law favors Sabbath observers over all other competing interests and, thus, "impermissibly advances a particular religious practice" (Estate v. Calder 1985, 710).

The United States also suffered defeat in two cases involving governmental aid to church-related activities. In Grand Rapids School District v. Ball (1985), for example, the Supreme Court again rejected accommodationist arguments and strongly reaffirmed its commitment to a line of cases supporting a strict separation of church and state. Specifically, the Court struck down two programs, Shared Time and Community Education, which used public school teachers and tax dollars to provide classes to nonpublic school children in classrooms located in and leased from the nonpublic schools. Shared Time offered remedial and enrichment classes that were intended to supplement Michigan's core curriculum. Teachers were full time employees of the public schools, though a "significant portion" had taught previously in nonpublic schools. In contrast, Community Education hired full-time parochial and nonpublic teachers as part-time public school employees, to provide certain courses in their respective private schools.

Participating as amicus curiae, the Reagan Administration conceded that the Lemon test, if "sensitively applied," was appropriate for resolving disputes involving governmental programs of assistance to the education of nonpublic school pupils. In urging the Court to uphold the Shared Time and Community Education programs, the Government stated that both sides accepted that improving the education of students, including those attending nonpublic schools, satisfied the secular purpose part of Lemon. At issue, however, was whether the programs advanced religion and/or involved government in excessive entanglement with religion. From the Government's perspective, the primary effect of both programs was neutral--"to broaden the educational opportunities of [all] school children . .." (Brief of U.S., Grand Rapids School District 1985, 13). Benefits flow directly to the schoolchildren and nonpublic schools are not relieved of any of their own educational costs or responsibilities. Nor is there any excessive governmental entanglement here. The solicitor general noted that the courses are strictly secular and guidelines were established to preserve the independence of both programs. Thus, Meek v. Pettinger (1975), where the court invalidated a similar program offered in nonpublic schools, was not controlling.

Writing for the Court, Justice Brennan agreed with the Government 
on one point: that the challenged programs ought to be measured against the Lemon criteria. In the majority's view, however, the programs violated the "primary effect" part of Lemon in three ways. First, as in Meek (1975), there was "a substantial risk of state-sponsored indoctrination" (Grand Rapids School District v. Ball 1985, 387), since no effort was made to monitor the programs for religious content. Second, the programs advanced religion through the establishment of a symbolic link between government and religion. "Government promotes religion as effectively when it fosters a close identification of its powers and responsibilities with those of any--or all--religious denominations as when it attempts to inculcate specific religious doctrines" (389). Moreover, the symbolism is not likely to adversely affect the impressionable minds of young children. Third, the establishment clause is violated because the Shared Time and Community Education programs promote religion by providing, in effect, a direct cash subsidy to the religious schools. ${ }^{2}$

Finally, the Court rejected Solicitor General Lee's accommodationist views in Aguilar v. Felton (1985). In a case similar to Grand Rapids, the Court struck down a remedial program under which New York City used funds received under Title I of the Elementary and Secondary Education Act to pay the salaries of public employees who taught disadvantaged students in religious as well as in public schools. The Court held that the use of publicly funded instructors to teach private school students in private school buildings violated the establishment clause of the First Amendment.

Arguing as the appellant, the Reagan Administration maintained that nothing in the Constitution required the adoption of an "unwelcome rule that Congress and the states are rigidly disabled from rendering secular remedial assistance to educationally deprived children in their own schools" (Brief of U.S., Aguilar 1985, 18).

As in Grand Rapids, the Government urged the Court to sustain the remedial program using the Lemon criteria. In its view, improving the education of needy students constituted a valid legislative purpose. Moreover, since aid was available to all eligible students on an equal basis, there was no advancement of religion. Anticipating that the major controversy was whether there was excessive entanglement, the solicitor general maintained that New York City's system of using public school authorities to monitor the religious content of publicly funded Title I classes satisfied the third part of Lemon. Finally, he made one last plea for the adoption of his accommodationist view of the establishment clause: 
The establishment Clause plays a harmonious role in the regime of religious liberty enshrined in our Constitution. To interpret it in so rigid and intolerant a spirit as to interfere with, rather than promote, that liberty would surely affront the intentions of the framers. It would be the ultimate constitutional irony, if, in the name of one of the Religion Clauses, educationally deprived children were to be denied benefits which are central to many aspects of a successful life solely because of choices that are themselves constitutionally protected (Brief of U.S., Aguilar 1985, 18).

Writing for a five justice majority, Justice Brennan concentrated on the one aspect that distinguished this case from Ball: the provision for governmental monitoring of the publicly funded instruction in the nonpublic schools. In his view, this monitoring resulted in an excessive entanglement of church and state. Moreover, the entanglement is unavoidable: "[i]n short, the religious school, which has as a primary purpose the advancement of and preservation of a particular religion must endure the ongoing presence of state personnel whose primary purpose is to monitor teachers and students in an attempt to guard against the infiltration of religious thought" (Aguilar v. Felton 1985, 413).

The solicitor general's approach received some support, albeit lukewarm, from the other justices. Justice Powell, concurring, agreed that the program had done much good and caused little if any harm. However, he still found violations under both the "primary effect" and "entanglement" prongs of Lemon. Chief Justice Burger came closer to the Government's position when, in his dissent, he concluded that the Court was exhibiting "nothing less than hostility toward religion and the children who attend church-sponsored schools" (Aguilar v. Felton 1985, 420). Justice Rehnquist also dissented, chiding the Court for creating a "Catch 22" paradox "whereby aid must be supervised to ensure no entanglement but the supervision itself is held to cause an entanglement" (421). Finally, Justice O'Connor went beyond Rex Lee's argument by calling for the excising of the entanglement prong from the Lemon test.

\section{The Later Reagan Years: Charles Fried as Solicitor General}

The Government participated in fewer establishment clause cases during the later Reagan years. This was especially evident in cases where the United States was not a direct party but might have participated as amicus curiae (see Edwards v. Aguillard 1987). Instead, the new solicitor general seemed to concentrate on church-state disputes involving the free exercise of religion, often arguing against accommodating religious diversity (for example, see Goldman v. Weinberger 1986). Nevertheless, 
the Administration was involved with a number of cases raising important establishment clause issues.

Public Funding for a Church Career. The Reagan Administration achieved success in Witters $v$. Washington Department of Services for the Blind (1986), where the Court held that the First Amendment did not prohibit a state from providing assistance to a blind person under its vocational rehabilitation program solely because the handicapped applicant chose to use the aid to prepare for a church oriented career at a Christian college.

Participating as amicus curiae, the solicitor general noted that there were several federal programs which provided financial assistance to college students for church-oriented and other careers. In its view, the vocational rehabilitation program provided "neutral" assistance in a manner that was consistent with original intent and past precedents. Arguing that the "overriding principle" was to prevent preference of one religious denomination over another, the solicitor general emphasized that there was a long tradition of federal assistance to both religious and secular institutions. And, as the court said in Mueller, there is no establishment clause violation when the Government provides financial assistance to individuals on a facially neutral basis and individuals themselves choose to use that aid for religious ends (Brief of U.S., Witters 1986, 9-10).

In addition, the Government maintained that the Washington State Supreme Court had erred in finding that the state's vocational assistance program failed to satisfy the Lemon test because it had the primary effect of advancing religion. Arguing again for the principle of "benevolent neutrality" as developed in Lynch v. Donnelly (1984), the solicitor general stated:

If a court focuses ... solely on the religious element [in a program] -- it will always find that the 'primary effect' is to advance (or inhibit) religion . . .. The "crucial question is not whether some benefit accrues to a religious institution as a consequence of the legislative program, but whether its principle or primary effect advances religion.' . . . To determine whether the religious effect is 'primary,' one must necessarily examine the effect in the context of the program as a whole (Brief of U.S., Witters 1986, 25).

Here, the effect of the rehabilitation program was the same as the purpose: providing vocational assistance to all persons falling within the category of the visually handicapped.

Writing for a unanimous Supreme Court, Justice Marshall agreed with the Government that the Washington Supreme Court had erred in finding that the state's program violated the "primary effect" part of 
Lemon. "Any aid provided under Washington's program that ultimately flows to religious institutions," explained Marshall, "does so only as a result of the genuinely independent and private choices of aid recipients" (Witters v. Washington Department of Services for the Blind 1986, 488). More controversial was the Court's statement that there was no advancement of religion because only one applicant used the assistance to prepare for a church career. Five concurring justices, coming closer to the Government's position, argued that this was a misreading of Mueller. As Justice Powell, joined by Chief Justice Burger and Justice Rehnquist, explained: "[n]owhere in Mueller did we analyze the effect of Minnesota's tax deduction on the parents who were the parties to the case; rather, we looked to the nature and consequence of the program viewed as a whole" (492).

Equal Access. The Reagan Administration was less successful in Bender v. Williamsport Area School District (1986), where it failed to convince the Supreme Court to decide whether the establishment clause was violated when a public high school permitted a student-initiated religious club to meet on school property during the regularly scheduled student activity period. In a 5 to 4 decision, the Court held that the respondent, who was not one of the litigants, lacked standing to appeal a lower court's decision with which he disagreed.

This had to be very disappointing to the Reagan Administration. The Bender case was important because it seemed to provide a way to bypass the Supreme Court's prayer decisions and to legitimize student religious activity in public schools. It was also consistent with its support of the Equal Access Act which prohibited schools that receive public funds from denying "equal access" to student groups on the basis of the political, philosophical, or religious content of the speech.

The solicitor general's major argument was that religious expression, as a form of free speech, was entitled to the same protection as other expression under the Constitution. He noted that the framers of the First Amendment "had no intention to place religionists or religious speech under any special disabilities, even within the public arena" (Brief of U.S., Bender 1986, 14-15). This view was taken by the Supreme Court in Widmar v. Vincent (1981) where it held that when facilities are made available to nonreligious groups on a state university campus during the school day they should also be made available to religious groups, since the First Amendment is content neutral. The solicitor general argued that this "equal access" principle should be applied to high school students since they are as capable as college students of learning "without confus- 
ing free expression with official orthodoxy" (19).

Four Supreme Court dissenters agreed with the solicitor general that Widmar was controlling. Justice Powell, for example, stated: "I do not believe--particularly in this age of massive media information--that the few years' difference in age between high school and college students justifies departing from Widmar" (Bender $v$. Williamsport Area School District 1985, 556). (This became the majority view during the Bush Administration when, in Board of Education of Westside Community Schools v. Mergens (1990), the Court held that the Equal Access Act did not violate the establishment clause).

Religious Discrimination. In Corporation of Presiding Bishop $v$. Amos (1987), the Supreme Court unanimously held that exempting the secular nonprofit activities of religious organizations from the religious anti-discrimination requirements of Title VII of the Civil Rights Act of 1964 did not violate the establishment clause of the First Amendment. Thus, it was permissible for the Mormon church to fire three of its employees who worked in church-owned corporations because they failed to satisfy the requirements for church membership.

The Government argued that the district court had erred in concluding that this congressional exemption from Title VII's prohibition against religious discrimination violated the "primary effect" and "excessive entanglement" parts of the Lemon formula. The purpose of this congressional exemption, explained Assistant Attorney General William Bradford Reynolds, was to ensure the separation of government and religion and to prevent government interference with sectarian organizations. Arguing that the establishment clause permitted government to foster "benevolent neutrality," the United States concluded that "Congress's decision to allow religious groups to use religion as an employment criterion free of government interference has the legitimate effect of accommodating religious institutions and furthering the separation of government and religion" (Jurisdictional Statement of U.S., Corporation of Presiding Bishop 1987, 14). Moreover, the third part of Lemon was satisfied because the exemption was specifically designed to eliminate government entanglement; without it, religious organizations would be subject to continuing supervision by the Equal Employment Opportunity Commission (20).

Finally, the Government suggested that, based on the logic of Marsh v. Chambers (1983) and Lynch v. Donnelly (1984), the Lemon standard was not appropriate for judging the constitutionality of a religious exemption "designed to accommodate religious beliefs and institu- 
tions . . ." (Jurisdictional Statement of U.S., Corporation of Presiding Bishop 1987, 18). Thus, the Court was urged to adopt still another exception to Lemon.

The Court, however, was unwilling to abandon Lemon. Justice White, writing for the Court, upheld the exemption under each part of this standard. He agreed with the United States that "to alleviate significant governmental interference with the ability of religious organizations to define and carry out their religious missions" (Corporation of Presiding Bishop v. Amos, 1987, 335) constituted a valid secular purpose. The Court also agreed with the Government that there had been no government advancement of religion. A law is not unconstitutional, explained White, merely because "it allows churches to advance religion, which is their very purpose" (337). And, the Court found that the exemption "easily passes muster" under the excessive entanglement part of Lemon.

Although four justices concurred, only Justice O'Connor addressed the appropriateness of using the Lemon formula in cases where the government seeks to accommodate the free exercise of religion. Quoting from her separate opinion in Wallace v. Jaffree (1985), O'Connor argued that official actions which advance religion are constitutional unless there is government "endorsement" of religion, which is not evident here.

Moment of Silence. In Karcher v. May (1987), an unanimous Supreme Court agreed with the Government and dismissed the case for want of jurisdiction. As a result, it was unnecessary for the Court to decide whether a New Jersey statute which provided for a daily moment of silence in public schools for "quiet and private contemplation" was constitutional under establishment clause standards. In his amicus curiae brief, however, the solicitor general addressed this question and found that this secular moment of silence law, which allowed students an "opportunity for unrestricted and uninterrupted reflection," satisfied the three part Lemon test.

Unlike Alabama in Wallace, the solicitor general found that New Jersey had enacted a facially neutral moment of silence law. In his view, the first part of Lemon is satisfied when government seeks to accommodate secular contemplation and "the desire of some students to dedicate themselves to God at the beginning of the school day as at the commencement of any serious enterprise" (Brief of U.S., Karcher 1987, 1718).

The idea that accommodating religion was a valid secular purpose was the major innovation by the solicitor general. However, the Government also argued that the moment of silence law met standards of "neu- 
trality" under the second part of Lemon in that no student was forced to pray, contemplate, or to do anything. "A better example of 'accommodation of all faiths . . . and hostility toward none'... would be difficult to find" (Brief of U.S., Karcher 1987, 28). Nor was there any excessive entanglement. From the solicitor general's view, moment of silence laws involved no more governmental intrusion than released time programs which had long since been found to meet establishment clause standards.

The Chastity Act. The Government won another major victory in Bowen v. Kendrick (1988), a decision that resolved several separate disputes, when the Supreme Court upheld, on its face, the constitutionality of the Adolescent Family Life Act (AFLA) which mandated the involvement of religious, charitable, and other voluntary organizations in a broad-scale effort to address the teenage pregnancy problem. On the related issue of whether AFLA was unconstitutional as applied, the Court asked the trial court to determine whether particular grants made to religious organizations violated the establishment clause.

As appellant and cross appellee, the Government argued that the district court had erred in holding AFLA unconstitutional. Specifically, it had failed to follow the Supreme Court's determination in Hunt $v$. McNair (1973) that religion is impermissibly advanced under Lemon only when assistance is given to pervasively religious organizations or to specifically religious activities in otherwise secular settings. Thus, the real question, never addressed by the district court, was whether AFLA funds had " flow[ed] to pervasively sectarian institutions . . ." (Reply Brief of U.S., Bowen 1988, 11, quoting Hunt v. McNair 1973, 743).

Also, the solicitor general rejected claims that the absence of a specific prohibition on using federal funds for religious purposes rendered AFLA invalid. In his view, Congress had provided clear directives on use of grants and none of the statutory objectives involved religious indoctrination or impermissible sectarian use. Finally, the Government disputed claims that AFLA involved excessive entanglement because of "simple" monitoring provisions designed to assure compliance. While "pervasively sectarian institutions" would require extensive monitoring, there was no evidence that such religious organizations were receiving AFLA funds.

Writing for a five justice majority, Chief Justice Rehnquist relied on the prior precedents suggested by the Government and upheld AFLA under each part of the Lemon test. Finding a legitimate secular purpose was easiest: Congress enacted the so-called "Chastity Act" for "the elimination or reduction of social and economic problems caused by 
teenage sexuality" (Bowen v. Kendrick 1988, 2571). More difficult was the issue of primary effect because religious organizations received federal funds and were involved in educating impressionable teenagers. Rehnquist argued that AFLA promoted "neutrality" since both religious and secular organizations could apply for funds. "[T]his Court has never held," explained the Chief Justice, "that religious institutions are disabled by the First Amendment from participating in publicly sponsored social welfare programs" (2574).

Chief Justice Rehnquist also adopted the solicitor general's argument that religion was advanced only when public funds were given to "pervasively sectarian" institutions. That danger seemed minimal under AFLA because its grant requirements for providing counseling services to adolescents were neutral on their face and could be met by a wide variety of religious and secular organizations. And "nothing in our prior cases warrants the presumption ... that religiously affiliated AFLA grantees are not capable of carrying out their functions . . in a lawful, secular manner" (Bowen v. Kendrick 1988, 2575-2576).

Rehnquist also agreed with the Government that the absence of a specific statutory prohibition on using public funds for religious purposes did not render AFLA unconstitutional. In his view, application, reporting, and evaluation requirements enabled the Secretary of Health and Human Services to monitor funding without "excessive entanglement" with religion.

In a separate concurring opinion, Justice Kennedy, joined by Antonin Scalia, expressed problems with the "pervasively sectarian" designation, suggesting that it was not "a well-founded juridical category ..." (Bowen v. Kendrick 1988, 2582). Rather, he urged, as the solicitor general had reasoned, that the district court look beyond the religious character of a grantee and concentrate on whether the grant was spent to further religion. Justice O'Connor, concurring, agreed and reminded the Court that the establishment clause was violated whenever public funds were used to promote religious doctrines.

The Government's position was rejected by Justice Blackmun who, joined by Justices Brennan, Marshall, and Stevens, emphasized that the Court had ignored most past precedents and had embraced a very narrow view of what constituted a "pervasively sectarian" institution. According to Blackmun, the nature of the activity, the lack of adequate safeguards, and past experience with the statute demonstrated that AFLA impermissibly promoted religion under the Lemon test. Moreover, the "excessive entanglement" element of this test was violated by the extensive monitor- 
ing required to assure that sectarian organizations did not use public funds for religious indoctrination during their counseling and teaching activities.

Holiday Displays. In County of Allegheny v. American Civil Liberties Union (1989), the Supreme Court considered the constitutionality of two recurring Christmas displays held on public property in the city of Pittsburgh. By a 5 to 4 margin, it disagreed with the solicitor general and found that a crèche displayed in the most public part of the county courthouse and bearing a banner proclaiming "Gloria in Excelsis Deo" constituted an endorsement of religion in violation of the establishment clause. However, by a 6 to 3 margin, the court agreed with the Government that the display of a Chanukah menorah, placed next to a Christmas tree just outside the City-County building and which included a mayoral statement saluting the "festive lights" of freedom, passed constitutional muster under the First Amendment.

Participating as amicus curiae, the Government sought to extend the Court's acknowledgment of "benevolent neutrality" in Lynch v. Donnelly (1984) to other "indirect, remote, and incidental" advancements of religion. As the solicitor general explained:

Religion is inextricably imbedded in our national culture and our official holidays and ceremonies, and it was never the purpose of the Establishment Clause to secularize our public life so rigidly that we cannot continue to make our public holidays in a manner that includes traditional acknowledgements of their religious character (Brief of U.S., County of Allegheny 1989, 10).

In his view, there was no difference between displaying a crèche in the courthouse, or a Christmas tree and menorah outside a government building, and the Christmas scene upheld in Lynch. Using Lemon, instead of the historical/ceremonial exception relied upon in Lynch, the Government had no problem in identifying the secular purpose: celebrating the holiday season.

Calling the crèche and menorah "passive symbols," the Government maintained that the "primary effect" part of Lemon had been satisfied in that there had been no government endorsement of religion. The effect of the displays was not to "coerce" belief or "compel" obedience to a particular religion or religious belief; rather, it was to foster " 'a friendly community spirit of goodwill in keeping with the season "” (Brief of U.S., County of Allegheny 1989, 15, quoting Lynch v. Donnelly 1984, 685). Nor was it significant that the crèche was not surrounded, as it had been in Pawtucket, with reindeer and other secular symbols. In an expansive 
reading of Lynch, the solicitor general maintained that "displaying a traditional symbol of a holiday--even if religious in origin and meaning-does not amount to an endorsement of the religious faith associated with the symbol" (17-18).

With respect to Pittsburgh's decision to erect a menorah next to its traditional Christmas tree, the Government argued that this was simply "recognizing another aspect of the holiday celebration" rather than giving preference to Judaism and Christianity. And, in a final section, the United states suggested that the Jeffersonian "wall of separation" was misleading in that a total separation would indicate hostility toward religion.

Writing for the Court, Justice Blackmun found the separate opinions of Lynch v. Donnelly (1984) more helpful than the "none too clear" majority opinion favored by the Government. He argued that to determine whether the government's use of religious symbolism satisfied the "primary effect" part of Lemon, the Court needed to examine the "context" of the display and then determine whether it had the effect of "endorsing" religious beliefs. In applying this standard to the crèche, Blackmun found that the display communicated a religious message, and unlike Lynch, there was nothing in the context of the display which detracted from this message. If anything, the "Glory to God in the Highest" inscription, the choral concerts held in the courthouse, and the placement of the display in the most beautiful and public part of the building tended to send "an unmistakable message that [the government] ... supports and promotes the Christian praise to God that is the crèche's religious message" (County of Allegheny v. American Civil Liberties Union 1989, 3104). And, despite what the solicitor general suggested, the Court affirmed the traditional view that the establishment clause prohibited all governmental endorsement of religion.

However, the Court agreed with the Government that the menorah/ Christmas tree display in front of the City-County Building was not an endorsement of Judaism and Christianity. While the menorah is a religious symbol, when combined with a Christmas tree--"the preeminent secular symbol of the Christmas holiday season"--and the mayor's statement on liberty, it becomes more a symbol of "cultural diversity" and part of celebrating the winter holidays than an endorsement of religious faith.

Of the four separate opinions submitted in this case, Justice Kennedy's is the most important. Joined by Chief Justice Rehnquist and Justices White and Scalia, Kennedy embraced and went beyond the solicitor 
general's arguments supporting the constitutionality of both holiday displays. Relying on the majority view in Marsh v. Chambers (1983) and Lynch v. Donnelly (1984), Kennedy called for a "substantial revision" of establishment clause doctrine and the abandonment of the endorsement test which he described as "flawed in its fundamentals and unworkable in practice" (Allegheny v. American Civil Liberties Union 1989, 3141). For Kennedy, virtually all accommodations of religious belief should be permitted; only governmental proselytizing should be prohibited under the establishment clause. ${ }^{3}$

\section{Conclusions}

Despite an increasingly conservative Supreme Court, the Reagan Administration was only moderately successful in convincing the Court to adopt its position in establishment of religion cases. Although Charles Fried succeeded more often than did Rex Lee, neither was able to persuade a majority of justices to abandon the Lemon standard. Both, however, had some success in winning support for the Administration's accommodationist interpretation of the establishment clause.

Prior research suggested that the Reagan Administration had good reason to expect success in its lobbying of the Supreme Court. The government generally has a high success rate before the Supreme Court, especially when participating as amicus curiae. Moreover, since ideological congruence between the justices and solicitor general has been found to affect outcome, it was hypothesized that a conservative Supreme Court would be amenable to the arguments made by a conservative executive branch.

At first, the Administration was successful. The Court followed its reasoning and suggested outcome in Mueller v. Allen (1983) and Marsh v. Chambers (1983). And, in Lynch v. Donnelly (1984), the Court agreed with the solicitor general that Pawtucket's Christmas display did not violate the establishment clause. Perhaps too much was made of these victories. Marsh, for example, involved an unusual ceremonial issue that was not amenable to traditional establishment clause analysis. Moreover, Mueller and Marsh were 5 to 4 decisions. The swing vote appeared to be that of Justice Powell, who supported accommodation in these instances but voted for stricter separation in later cases. In Lynch, the Court refused Rex Lee's suggestion to reconsider the Lemon test or to accept the legitimacy of government endorsement of religion in American life.

The 1984-85 term, Rex Lee's last as solicitor general, was espe- 
cially disappointing to the Reagan Administration. In three major cases (Alabama's silent moment and two parochial aid controversies), the Administration suffered setbacks. The Court refused to adopt either the position or the pro-accommodationist arguments of the Administration. The Administration's disappointment is seen in "aftermath" comments. Attorney General Meese, for example, found the religion decisions "bizarre," while Secretary of Education Bennett maintained that the Court had shown a "fastidious disdain for religion" (New York Times, July 3, $1985,11)$.

Some new right conservatives blamed Lee for these setbacks. One complaint is that Lee never urged the court to overrule the school prayer or other "liberal" decisions of the Warren Court era. More damaging, the editor of Benchmark, a conservative legal journal, argued that "we find that he has repeatedly taken positions that are directly at odds with the President's program and has regularly advanced points of law that are calculated to preserve intact existing case law and the doctrines of the Supreme Court" (Benchmark 1984, 2). Perhaps this is why Caplan $(1988,105)$ reports that, by 1985 , Associate Attorney General William Bradford Reynolds had already become the "shadow solicitor."

While Rex Lee $(1981,131-32)$ supported the Supreme Court's prayer decisions prior to becoming solicitor general, there is little evidence to suggest that his inability to fundamentally alter the Court's approach in church-state disputes resulted from personal policy preferences. Rather, it appears that Lee subscribed to the traditional role of the solicitor general. As he explained to Caplan in an interview soon after his resignation:

If I had done what was urged on me in a lot of cases, I would have lost those cases and the Justices wouldn't have taken me seriously in others. There has been this notion that my job is to press the Administration's policies at every turn and announce true conservative principles through the pages of my briefs. It is not. I'm the Solicitor General, not the Pamphleteer General $(1988,107)$.

Charles Fried was more successful than Rex Lee in lobbying the Supreme Court with respect to case outcome, but he was unable to convince the Supreme Court to abandon Lemon or to reformulate the "primary effect" part so as to protect governmental activities which promoted the free exercise of religion. One reason for his partial success was an apparent willingness to limit participation in establishment clause cases. As O'Connor (1983) and Baum (1989) have noted, the solicitor general is 
most successful when exercising restraint in bringing cases to the Court. This was a marked departure from Rex Lee's last term when the United States participated, either as a direct party or as amicus curiae, in each of the docketed cases.

Yet, the Reagan Administration failed to produce major change in the Supreme Court's interpretation of the establishment clause. It was unable to promote significant accommodation by lowering the "wall of separation" between church and state. Therefore, past Warren Court precedents, including the much criticized school prayer decisions, were not reversed. Most important, the framework for resolving establishment clause disputes, the Lemon test, was reaffirmed by a majority of the justices. This reaffirmation seemed to affect the solicitor general's approach, as both Lee and Fried relied on Lemon criteria following court rejection of their calls for abandonment.

However, the Lemon test may be in jeopardy. Chief Justice Rehnquist has called for total abandonment. Justice Scalia has challenged the "secular purpose" prong. Justice O'Connor would eliminate the "excessive entanglement" part. Justices White and Kennedy have gone even further, questioning the historical validity of the "wall of separation" metaphor and suggesting the necessity of reevaluating all prior establishment clause cases based on Lemon. And, with the retirement of Justice Brennan, it appears that only Justices Marshall, Blackmun, and Stevens support all three parts of this formula.

In the final analysis, the solicitor general may not be the appropriate individual to advance the President's "social agenda." He may be a representative of the executive branch, but his effectiveness before the Supreme Court seems related to his being independent of partisan politics. As former Solicitor General Erwin N. Griswold (1971, 353) has explained: "the Solicitor General's function is essentially professional."

\section{NOTES}

${ }^{1}$ Two cases were decided by an evenly divided Court because Justice Powell did not participate. See Board of Trustees of Village of Scarsdale v. McCreary (1985) and Jensen v. Quaring (1985).

${ }^{2}$ The Government received some support from Chief Justice Burger and Justice O'Connor who, in separate opinions, concurred with the Court on the Community Education program but dissented with respect to Shared Time.

${ }^{3}$ On the other side, Justices Brennan, Blackmun, and Stevens completed rejected the Government's reasoning. They found that both displays violated the establishment clause. 


\section{REFERENCES}

Abington School District v. Schempp. 1963. 374 U.S. 203.

Aguilar v. Felton. 1985. 473 U.S. 402.

Baum, Lawrence. 1989. The Supreme Court, 3rd ed. Washington, DC.: CQ Press.

Benchmark. 1984. "A Lawyer Looks at Rex Lee." Benchmark 1:1-15.

Bender v. Williamsport Area School District. 1986. 474 U.S. 534.

Board of Education of Westside Community Schools v. Mergens. 1990. 110 S.Ct. 2356.

Board of Trustees of Village of Scarsdale v. McCreary. 1985. 471 U.S. 83.

Bowen v. Kendrick. 1988. 108 S.Ct. 2562.

Briefs of the United States. In the Supreme Court of the United States. Department of Justice: $1982-83$ to $1988-89$ Terms.

Caplan, Lincoln. 1988. The Tenth Justice: The Solicitor General and the Rule of Law.

New York: Vintage Books.

Congressional Record. 1984. 98th Congress, 2nd session, Vol. 130.

Corporation of Presiding Bishop v. Amos. 1987. 483 U.S. 327.

County of Allegheny v. American Civil Liberties Union. 1989. 109 S.Ct. 3086.

Edwards v. Aguillard. 1987. 482 U.S. 578.

Engel v. Vitale. 1962.370 U.S. 421.

Estate of Thornton v. Caldor, Inc. 1985. 472 U.S. 703.

Everson v. Board of Education. 1947. 330 U.S. 1.

Glazer, Nathan. 1986. "Social Agenda." In Perspectives on the Reagan Years, ed.

John J. Palmer. Washington, DC.: The Urban Institute.

Goldman, Sheldon. 1985. "Reaganizing the Judiciary." Judicature 69: 324-329. . 1989. "Reagan's Judicial Legacy." Judicature 72: 328-330.

Goldman v. Weinberger. 1986. 475 U.S. 503.

Grand Rapids School District v. Ball. 1985. 473 U.S. 373.

Griswold, Erwin N. 1971. "Constitutional Cases in the Supreme Court." Oklahoma Law Review 24: 353-364.

Hunt v. McNair. 1973. 413 U.S. 734.

Jensen v. Quaring. 1985. 472 U.S. 478.

Karcher v. May. 1987. 108 S.Ct. 388.

Lee, Rex. 1981. A Lawyer Looks at the Constitution. Provo, Utah: Brigham Young University Press.

Lemon v. Kurtzman. 1971. 403 U.S. 602.

Lynch v. Donnelly. 1984. 465 U.S. 668.

Marsh v. Chambers. 1983. 463 U.S. 783.

Meek v. Pettinger. 1975. 421 U.S. 349.

Miller, Arthur Selwyn. 1968. "The Attorney General as the President's Lawyer." In Roles of the Attorney General of the United States. Washington, DC.: American Enterprise Institute.

Mueller v. Allen. 1983. 463 U.S. 388.

New York Times. 3 July 1985: 11.

O'Connor, Karen. 1983. "The Amicus Curiae Role of the U.S. Solicitor General in Supreme Court Litigation." Judicature 66: 257-264.

Puro, Steven. 1981. "The United States as Amicus Curiae." In Courts, Law and Judicial Processes, ed. S. Sidney Ulmer. New York: The Free Press. 
Scigliano, Robert. 1971. The Supreme Court and the American Presidency. New York: The Free Press.

Segal, Jeffrey A. 1988. "Amicus Curiae Briefs by the Solicitor General During the Warren and Burger Courts." Western Political Quarterly 41: 135-144.

Senate Judiciary Committee. 1982. Proposed Amendments Relating to Voluntary Prayer: Hearings on SJ 199. 97th Congress, 2nd session.

Stern, Robert L., Eugene Gressman and Stephen M. Shapiro. 1978. Supreme Court Practice, 5th ed. Washington, D.C.: Bureau of National Affairs.

Uelmen, Gerald F. 1986. "The Influence of the Solicitor General Upon Supreme Court Disposition of Federal Circuit Decisions: A Closer Look at the Ninth Circuit Record." Judicature 69: 360-365.

Wallace v. Jaffree. 1985. 472 U.S. 38.

Wasby, Stephen L. 1984. The Supreme Court in the Federal Judicial System, 2nd ed. New York: Holt, Rinehart and Winston.

Witt, Elder. 1986. "Reagan Crusade Before Court Unprecedented in Intensity." Congressional Quarterly Weekly Report March 15, 1986: 616-618.

Witters v. Washington Department of Services of the Blind. 1986. 474 U.S. 481.

Yale Law Journal. 1969. "Government Litigation in the Supreme Court: The Roles of the Solicitor General." Vol. 78: 1442-1481.

Zorach v. Clauson. 1952. 353 U. S. 306. 